\title{
The Trump Administration and the United States' China Engagement Policy
}

\author{
Author: Khoo, Nicholas
}

To cite this article: Khoo, N. (2021). The Trump Administration and the United States'

China Engagement Policy. National Security Journal, 3(2). doi: 10.36878/nsj20210317.01

To link to this article: https://doi.org/10.36878/nsj20210317.01

View CrossRef data: https://search.crossref.org/?q=10.36878\%2Fnsj20210317.01 


\title{
THE TRUMP ADMINISTRATION AND THE UNITED STATES' CHINA ENGAGEMENT POLICY
}

\begin{abstract}
Nicholas Khoo ${ }^{1}$
The longstanding post-1972 consensus supporting a US policy of engagement with China has been eroded by increasing dissatisfaction with developments in China's domestic and foreign policies. As a consequence, a policy of near full-spectrum US engagement has been replaced by a more conditional posture where conflict increasingly outweighs cooperation. This article describes the relationship's breakdown during the Trump administration. It then evaluates two major competing explanations for the deterioration. These emphasise either the role of the concept of identity, or aspects of power politics, specifically, state interests and the distribution of capabilities. In a concluding section, the implications of a more confrontational Sino-US relationship for New Zealand are discussed.
\end{abstract}

Keywords: US engagement policy; Sino-US conflict; identity; neorealism; state interests; distribution of capabilities; New Zealand non-alignment.

\section{Introduction}

US-China relations have faced many challenges since Richard Nixon and Mao Zedong brokered a dramatic diplomatic rapprochement in 1972, but none as serious as the present. ${ }^{1}$ At the present time, contention is the dominant characteristic in issue areas ranging from trade and military affairs, to human rights and democracy. Indeed, even before the Trump administration came to power, a consensus had developed among US China specialists that US engagement policy with China had failed, even as debate existed on what policy to replace it with. ${ }^{2}$ Thus, in 2015, Harry Harding, a leading China expert, lamented the poor state of the US-China relationship. According to Harding, "present [US China] policy is widely believed to have failed." ${ }^{3}$ Looking to the future, his concern was that the US-China relationship would become "essentially competi-

$1 \quad$ Nicholas Khoo is Associate Professor in the Politics Programme at the University of Otago. He thanks Peter Grace, Reuben Steff, and John Tai for comments on this article. 
tive or even degenerate into open rivalry". ${ }^{4}$ That time has come. Since 2017, there has been open acknowledgement in the United States of "geopolitical competition" 5 and "strategic competition" with China, and serious discussion of how to "decouple" the relationship. ${ }^{7}$ Meanwhile, the Chinese perspective is that policies pursued by the US, particularly during the Trump presidency, are responsible for the present state of the relationship. ${ }^{8}$ As the Biden administration takes over the policy reins, this article establishes that the era of a near full-spectrum US policy of engagement with China has ended, ${ }^{9}$ replaced by a more conditional posture that reflects a greater US tolerance for conflict. ${ }^{10}$ It then proceeds to evaluate two major competing explanations for this development. These emphasise either the role of the concept of identity, or aspects of power politics-specifically, state interests and the distribution of capabilities. A final section discusses the implications of heightened Sino-US rivalry for New Zealand.

\section{A Policy Unraveled}

The unraveling of the US policy of engagement with China occurred over a sustained period in the post-Cold War era, culminating in the Trump administration's adoption of a policy designed to actively seek changes in Chinese behavior in multiple spheres, both domestic and international. The first major document outlining this change was the administration's December 2017 National Security Strategy (NSS). In an interview to introduce the NSS, National Security Adviser Herbert McMaster commented that China was a "revisionist power" that "was undermining the international order." ${ }^{11}$ In a significant departure, the NSS questioned the fundamental premise of engagement that had underpinned US China policy since 1972. ${ }^{12}$ The NSS opined that "China seeks to displace the United States in the Indo-Pacific region,"13 a region where Beijing is "using economic inducements and penalties, influence operations, and implied military threats to persuade other states to heed its political and security agenda." ${ }^{14}$ While critical of aspects of Chinese policy, the three previous NSS documents (in 2002, 2010 and 2015), had not adopted such stark language. These reports referenced "managing competition from a position of strength," 15 underlined that "a pragmatic and effective relationship between the United States and China is essential to address the major challenges of the $21^{\text {st }}$ century," ${ }^{\prime 16}$ and emphasised co-operation even while acknowledging differences. ${ }^{17}$

The administration's January 2018 National Defense Strategy doubled down on the new line, noting that "the central challenge to US prosperity and security is the re-emergence of long-term, strategic competition by...revisionist powers," a category which it identified as including, among others, China and Russia. ${ }^{18}$ The document reintroduced the concept - previously used in 2000 by then presidential candidate George W. Bush ${ }^{19}$ that China is a "strategic competitor" of the US. ${ }^{20}$ The 2019 Department of Defense Indo-Pacific Strategy report buttressed this perspective, cataloguing China's revisionist policy practices, ${ }^{21}$ even while highlighting the erosion of the US's regional deterrence 
posture. ${ }^{22}$ This was followed by the February 2020 United States Strategic Approach to the People's Republic of China report, which called for a "clear-eyed assessment of the Chinese Communist Party's intentions and actions, a reappraisal of the United States' many strategic advantages and shortfalls, and a tolerance of greater bilateral friction." ${ }^{23}$

Given that China's post-1978 economic growth model has been predicated on a robust relationship with the US, the unraveling of US engagement policy is a disastrous outcome..$^{24}$ Nonetheless, at the same time, this development is also a confirmation of a longstanding Chinese world-view. To be specific, there has been a persistent assertion by both official and non-official Chinese sources of the US's alleged malign view of China's rise. As early as the 1990's, references were being made by Chinese analysts to a US intent to 'contain' China's rise. ${ }^{25}$ This feature of Chinese commentary has strengthened over time. In a not so-veiled reference to the US, a Chinese government Defence White Paper released in October 2000 declared that: "No fundamental change has been made in the old, unfair and irrational international political and economic order. Certain big powers are pursuing 'neo-interventionism,' 'neo-gunboat diplomacy,' and 'neo-economic colonialism,' which are seriously damaging the sovereignty, independence, and developmental interests of many countries, and threatening world peace and security." ${ }^{\prime 26}$ No doubt, this stance reflected the incoming George W. Bush administration's more robust stance toward China during that year's presidential campaign. Despite a contentious start that was marked by the EP-3 crisis of April 2001, the imperative of prosecuting the Global War on Terror after 9/11 focused US attention on maintaining a stable relationship with China throughout Bush's two-term tenure, ${ }^{27}$ even as it kept its eye on balancing China's rising power. ${ }^{28}$ Frictions intensified as the Obama administration responded to China's growing post-2008 global financial crisis power position by articulating a 'rebalancing' to the Indo-Pacific policy over the course of the 2010-2011 period. ${ }^{29}$ The Chinese reaction to this development was far from monolithic..$^{30}$ Nevertheless, it was not uncommon to hear recycled claims from Chinese academics that the US was adopting a policy "posture [that is] seemingly intent to contain China." ${ }^{31}$

And Chinese grievances have escalated with the Trump administration's adoption of a more robust China policy, exemplified by US trade policy since early $2018 .^{32}$ This watershed development was underpinned by longstanding and specific complaints by the US Treasury Representative's Office..$^{33}$ It quickly became clear to the Chinese leadership that the US was not going to back down on its demand for a renegotiation of the economic relationship. Accordingly, a Phase One agreement was reached in late 2019, taking effect on 15 January $2020 . .^{34}$ In an ironic twist, Trump's signature achievement on China was torpedoed by a combination of idiosyncrasies. Specifically, the Chinese Communist Party (CCP) leadership's historically well-established proclivity to place the party's image before their citizens' health interacted with President Trump's bizarre 
decision-making in respect to the coronavirus pandemic, with catastrophic consequences. ${ }^{35}$ Despite having been directly and repeatedly notified of the pandemic in January, Trump took what is manifestly insufficient action. ${ }^{36}$ As a consequence, we have a full-blown global health crisis, with nearly 500,000 American deaths registered to date, the highest of any country in the world. ${ }^{37}$ There is now no realistic way for China to meet the terms of the agreement. ${ }^{38}$ And, to compound matters, rather than cooperate to solve the most pressing international health crisis in a century, Beijing ${ }^{39}$ and Washington have politicised the issue. ${ }^{40}$

In the meantime, the US has hardened its stance on China. The administration laid out its critique of China in a systematic quartet of public speeches over the June-July 2020 period. These involved the National Security Advisor, the FBI Director, the Attorney General, and the Secretary of State. ${ }^{41}$ Indeed, it is difficult to think of a sphere in the relationship that has not been targeted by the administration. ${ }^{42}$ US sanctions on China have ranged from adding Chinese entities ${ }^{43}$ to two separate blacklists, the first list overseen by the Commerce Department and the second managed by the Department of Defense; ${ }^{44}$ requiring Chinese news agencies operating in the US to register foreign government operatives, thus subjecting them to the same rules governing Chinese diplomats; ${ }^{45}$ barring specific Chinese officials responsible for implementing its widely criticised national security law on Hong Kong from entry into the US; ${ }^{46}$ enacting legislation against US investments in companies owned or operated by the Chinese military; ${ }^{47}$ reaching a finding that China is pursuing a policy of genocide toward its Uighur minority in Xinjiang; ${ }^{48}$ tightening visa rules for Chinese Communist Party members who visit the United States; ${ }^{49}$ launching a vast investigation of Chinese efforts to acquire research by scientists employed by US universities and research institutes, ${ }^{50}$ even as the administration publicly warns of China's efforts to exploit US universities in various ways; ${ }^{51}$ and targeting Beijing's strategic neuralgia by deepening US relations with Taiwan. ${ }^{52}$

These actions have prompted a furious Chinese response. On 25 May 2020, Chinese Foreign Minister Wang Yi declared that American politicians "are taking China-US relations hostage and pushing us to the brink of a new Cold War." ${ }^{33}$ On 9 July, Wang opined that the China-US relationship "is faced with the most severe challenge since the establishment of diplomatic ties." ${ }^{54}$ In his view, the US's China policy has reached a "point of paranoia" where "it seems as if every Chinese investment is politically driven, every Chinese student is a spy, and every cooperation initiative is a scheme with hidden agenda." 55 Tensions culminated on 24 July, with the Trump administration's decision to order the closure of China's consulate in Houston, the charge being that it was serving as a hub for espionage activities. ${ }^{56}$ It bears noting that Chinese media focused particular fury on US Secretary of State Mike Pompeo. ${ }^{57}$ 
Even as the Chinese government invoked the spectre of a 'New Cold War', the Trump administration contended that the metaphor was an inadequate one to characterise bilateral conflict. An authoritative 2019 Chinese government White Paper on China's role in the world lauded the contributions of its post-1978 development model, counseling that "cooperation is the only correct choice for the two countries,"58 before advising that "the US should abandon the Cold War mentality," ${ }^{19}$ and disassociate itself from a "surging" trend in world politics of "hegemonism and power politics." ${ }^{60}$ Echoing this line, Chinese foreign ministry official Hua Chunying "urge[d] relevant officials in the United States to abandon the Cold-War mentality and zero-sum game mindset, adopt an objective and rational view towards China and China-US relations, and focus more on promoting mutually beneficial cooperation to better serve the two peoples and the people around the world." ${ }^{\prime 1}$ For its part, the Trump administration rejected the containment metaphor, pointing out that the challenge presented by China represents a level of complexity that exceeds that of the Soviet Union. Thus, Secretary of State Mike Pompeo noted: "This isn't about containment. Don't buy that. It's about a complex new challenge that weve never faced before. The USSR was closed off from the free world. Communist China is already within our borders." ${ }^{2}$

\section{Explaining the Unravelling}

How can we explain the unravelling of the US engagement policy with China, and the accompanying tolerance for a relationship where aspects of conflict prevail over cooperation? Space considerations limit our review to what are arguably the two most influential explanations-identity theory and neorealist theory.

There is a burgeoning research programme on the concept of identity in great power politics, where the China-US relationship is prominently featured..$^{63}$ Identity as a source of intense conflict in US-China relations comports with the rhetoric of some of the major participants in the relationship. ${ }^{64}$ On the US side, various reports since 2017 have juxtaposed ideological regime differences with standard inter-state power struggle to explain the deterioration in relations. ${ }^{65}$ Thus, the 2017 NSS described the Sino-US relationship as one of the "power contests" facing the US in world politics, which it characterised as "fundamentally political contests between those who favour repressive systems and those who favour free societies."66 In his introductory statement for the 2019 Department of Defense Indo-Pacific Strategy report, Defense Secretary Patrick Shanahan singled out the CCP-led China as typifying the phenomenon of "inter-state strategic competition" where "geopolitical rivalry between free and oppressive world order visions" is "the primary concern for US national security." ${ }^{\text {" Th }}$ The February 2020 United States Strategic Approach to the People's Republic of China report added specificity to this, acknowledging "long-term strategic competition between our two systems," ${ }^{8}$ "a system rooted in Beijing's interpretation of Marxism-Leninism ideology", ${ }^{19}$ and calling for "a competitive approach to the People's Republic of China." ${ }^{70}$ Finally, the State 
Department Policy Planning Staff's November 2020 report on China noted that "the Chinese Communist Party has triggered a new era of great power competition," ${ }^{11}$ stating that "in the face of the China challenge, the United States must secure freedom."72

The emphasis by the US on regime-based identity differences has been mirrored by China. That this has occurred is also not surprising. China's state identity manifestly reflects its Marxist-Leninist ideology, with the CCP at the vanguard. The leadership of the Peoples' Republic of China views itself as an exemplar of a state that practices "Socialism with Chinese Characteristics," which according to Xi Jinping, the President and Secretary-General of the CCP, offers "a new option for other countries and nations that want to speed up their development while retaining their identity." "73 And central to PRC identity are the "Four Cardinal Principles," first articulated by Deng Xiaoping in 1979, and advanced as the "basic prerequisite for achieving modernization." ${ }^{34}$ These principles are enshrined in the Constitution of the People's Republic of China, establishing the Party's dominance over China's politics and society on a Marxist-Leninist basis. ${ }^{75}$ And, consistent with the foundational Marxist-Leninist texts, the Chinese leadership believes in "building a socialism that is superior to capitalism, laying the foundation for a future where we will win the initiative and have the dominant position." 76

The differences in the two state's identity-based self-perceptions are stark. And so are the differences on the significance of these diverging identities. In the Chinese selfconception, a Marxist-Leninist China pursues an "independent foreign policy of peace" and "will never seek hegemony or engage in expansion."77 Accordingly, China "absolutely reject[s] the Cold War mentality and power politics." ${ }^{78}$ In contrast, US Secretary of State Mike Pompeo has highlighted the CCP's identity as a source of conflict in bilateral relations, declaring in early 2020 that the CCP is "the central threat of our times." ${ }^{\prime \prime 9}$ In Pompeo's view, "today, China is increasingly authoritarian at home, and more aggressive in its hostility to freedom everywhere else.... If the free world doesn't change Communist China, Communist China will change us." ${ }^{80}$ Accordingly, "the old paradigm of blind engagement with China simply won't get it done. We must not continue it. We must not return to it." ${ }^{\text {1 }}$

The Sino-US dyad manifestly involves states with deeply contrasting identities, but what is the specific causal role and impact of identity in the bilateral relationship? Are identity dynamics the reason for the unravelling of the US engagement policy, and with it, the wider Sino-US relationship? Closer inspection suggests important empirical and methodological reasons for caution.

First, while recognising that some level of identity-based friction is inevitable in relations between states organised on such different governing principles, substantial empirical evidence suggests that the US is able to confidently coexist with a Chinese communist state that does not share its liberal democratic capitalist identity. ${ }^{82} \mathrm{~A}$ similar generalisation can be made for China. Despite significant identity-based differences, 
the US has had a very robust engagement policy with China since 1972. In broad terms, the Chinese economic miracle is "Made in the USA." The US has been the top export market for China for much of the post-1972 era. Not to put too fine a point on it, without the ability to export to the US market, there would be no China economic miracle. And China has been a major export market for the US. ${ }^{83}$

The goal of US engagement policy since 1972 has been to substantially affect Chinese foreign and domestic policy, to incentivise China to operate in ways that are consistent with US interests. ${ }^{84}$ To this end, US engagement policy has survived a number of specific and serious challenges in the post-Cold War era including: the CCP's Tiananmen era crackdown from 1989-92; the Clinton administration's MFN-Human Rights linkage policy from 1993-94; the Taiwan Straits crisis of 1995-96; and Taiwanese leader Chen Shuibian's disruptive role in the Sino-US relationship from 2001-08. Until very recently, the US successfully balanced the imperative to provide for its own security as well as its alliance partners in the strategically significant East Asian region, even while integrating China into the international system. The near full-spectrum version of this policy was a strategic choice which yielded substantial benefits to the US and its regional allies and partners, but has clearly run its course. To the extent that serious conflict has erupted, as discussed below in the section on neorealist theory, it is principally because China has acquired the capabilities and the resolve to challenge US policy in East Asia in the post-2008 era that Washington has had to engage in sustained pushback against Chinese policy.

Second, as part of a broader identity research programme, it is unclear if the concept provides us with sufficient conceptual leverage to cogently analyse US-China relations. In this respect, analysts who have posited identity as the principal determinant in Chinese foreign policy are now either unable to explain China's turn toward a more contentious stance, and/or are implausibly citing changes in the identity concept as reasons for pessimism. For example, in focusing on identity as a core explanatory variable, ${ }^{85}$ Kang contends that fears over China's rise are "empirically unfounded," ${ }^{86}$ and that there exists a strong shared regional understanding about "China's preferences and limited aims." ${ }^{87}$ In this view, rather than viewing China as a threat, present-day East Asian states are mimicking their predecessors in previous epochs who identified Chinese regional hegemony with stability. ${ }^{88}$ Kang's perspective is simply unable to provide a convincing explanation for China's more robust post-2009 foreign policy. ${ }^{89}$ Alternatively, David Shambaugh argued in 2005 that China was gradually shedding its "identity of historical victim." ${ }^{90}$ However, just a few years later, identity is cited as the key reason for an increasingly assertive Chinese Asia policy. ${ }^{91}$ Could China's state identity have changed so quickly? This seems highly unlikely. Indeed, if identity is so malleable, it draws our attention to the fact that the claims on behalf of the concept are a case of spurious causation, masking the operation of more fundamental variables outlined below. 


\section{Neo-Realist Theory and the United States' China Engagement Policy}

How then can we explain the trajectory of the United States' China engagement policy? Two reasons-the timing of contemporary Sino-US conflict escalation and the historical record of US relations with non-liberal democratic states-strongly suggest that the course of the relationship is more convincingly understood with reference to concepts in neorealist theory-the distribution of capabilities and state interests. ${ }^{92}$ Moreover, moving forward, in practical policy terms, an interest based US policy toward China is much more likely to sustain a workable relationship than one based on identity convergence.

First, consider the timing of conflict escalation in the Sino-US relationship. Bilateral relations from 1991-2008 were far from smooth. ${ }^{93}$ But it was only at the tail end of the $\mathrm{Hu}$ Jintao era, and particularly after Xi Jinping assumed the mantle of CCP Secretary General in November 2012, and sought to systematically project China's rapidly expanding post-2008-09 global financial crisis power onto the international sphere, that the US responded with the adoption of a more robust China policy. In other words, bilateral relations sharply deteriorated after China acquired sufficient material capabilities and demonstrated a revisionist state posture toward US regional interests. ${ }^{94}$ This point is recognised even in what is arguably the US government's most identity-focused report on China in recent years, the State Department's 2020 Elements of the China Challenge. Notwithstanding the report's heavy focus on aspects of China's ideological identity and emphasis on its corrosive role in bilateral relations, ${ }^{95}$ it nevertheless states that ultimately, "China is a challenge because of its conduct." ${ }^{36}$ This makes eminent sense since China's identity as a Marxist-Leninist state has remained broadly constant throughout the post-1978 reform era, while its conduct has changed because of rising capabilities and revisionist state interests.

Second, a review of the historical record of US relations with non-liberal democratic states suggests that a state's values, a synonym for identity, are a significant problem in bilateral relations only when there is already an underlying strategic competition based on the balance of power and conflicting state interests. The most prominent example in this respect is the US-Soviet relationship, where cooperation with the Soviet Union during World War Two was replaced by intense Cold War rivalry. ${ }^{97}$ As in the contemporary China case noted above, Soviet identity remained broadly constant throughout this period. What changed was Moscow's capabilities to challenge US foreign policy. For states that are not in strategic competition with the US, a state's identity and values present no barrier to cooperation. The US has a well-established record of cooperating with states with vastly different ideological identities. ${ }^{98}$ Indeed, the Sino-US containment of Soviet power in the second-half of the Cold War is one of the most prominent examples of this phenomenon. ${ }^{99}$ This historical pattern in US foreign policy continues to this day. Thus, the US NSS 2017 report highlighted China's authoritarian ideology $y^{100}$ 
as a major problem in Sino-US bilateral relations, even while stressing that in its relations with allies and partners, many of whom are not liberal democratic, "we are not going to impose our values on others." 101

Third, an interest rather identity-based relationship has a much greater likelihood of being sustained by Beijing and Washington. It is important to note that notwithstanding copious discussion highlighting ideological differences, key Trump administration documents on China are careful to specify a US willingness to cooperate with China when interests overlap. The 2017 National Security Strategy notes that Chinese "intentions are not fixed," and that the US "stands ready to cooperate across areas of mutual interest (italics added)." ${ }^{102}$ Similarly, the 2019 Indo-Pacific Strategy report states that "the United States is prepared to support China's choices to the extent that China promotes long-term peace and prosperity for all in the Indo-Pacific, and we remain open to cooperate where our interests align (italics added)." 103 The 2020 President's Office report states that "we welcome cooperation when our interests align (italics added)."104 On this score, it is encouraging that President Biden has repeated that the US "is ready to work with Beijing when it is in our interest to do so," ${ }^{105}$ even as he has described China as the US's "most serious competitor." ${ }^{106}$ And, it bears noting that given Biden's less divisive international posture than Trump, some Chinese expect him to be more effective than his predecessor in exerting US pressure on China. ${ }^{107}$

\section{US-China Relations in a Biden Presidency: Implications for New Zealand}

The policy consequences for New Zealand of a correct understanding of the basic causes of the unravelling of the US engagement policy with China in the post-2020 US Presidential election era cannot be overstated. A China that is viewed by the US as a challenge because of its Marxist-Leninist identity is an existential threat, where coexistence is an unacceptable outcome. In contrast, a China that is viewed as a challenge because of its expanding capabilities is one that, even if it poses a considerable problem for US policy, can conceivably be managed with a judicious combination of engagement, internal economic restructuring, inter-state balancing, and alliance management.

New Zealand understandably seeks to sustain a relationship with both China and the United States. In the face of escalating conflict between the US and China, can New Zealand weather the ensuing storm? Precisely because both China and the US are seeking as many partners and allies in their emerging competition, there is reason for cautious optimism in the short-run. That said, this interregnum is neither reason for complacency, nor a substitute for hard-headed analysis of New Zealand's options. Certainly, as David Parker, the previous Minister for Trade and Export Growth has affirmed, there needs to be a diversification and consolidation of New Zealand's economic partnerships, even as preparation is made for an increasingly less benign external security environment. ${ }^{108}$ In this respect, negotiating a US-New Zealand Free Trade Agreement to match the China-New Zealand Free Trade Agreement makes eminent sense. ${ }^{109}$ 
Beyond the short-term, Wellington's dilemma, which is similar to that of multiple states in the Asia-Pacific is this: what is the appropriate foreign policy to adopt when our number one trading partner (China since 2017), is also in a rivalry relationship with the state that underpins our regional security since 1945 (the US)? It is difficult to think of a more challenging strategic conundrum for New Zealand. Structural incentives reinforce Wellington's psychological preference for non-alignment. As a preferred policy option, significant structural economic and domestic political incentives point in the way of New Zealand seeking to maintain a position of non-alignment in a bipolar Sino-US regional order. Non-alignment has the benefit of maintaining the trade and investment link with China while establishing a minimum basis for cooperation with the US across a spectrum of issues. The question is whether this posture, which frankly, has been Wellington's de facto policy throughout the post-Cold War era, is sustainable in the face of escalating US-China rivalry. This remains to be seen. But even if nonalignment is achievable for Wellington, it is an illusion to think that it will be costless. For one thing, New Zealand will lose the maximal benefits of alignment with either China or the US. Worse still, nonalignment may easily backfire. How so? Non-alignment may very well be interpreted as neutrality to Wellington; it could easily mean something else to Beijing and Washington. Wellington could end up in a situation where either (or both) Beijing and Washington equate nonalignment with appeasement, opening the door to various levels of implicit or explicit coercive diplomacy from these states. Our remaining analysis focuses on the status of Wellington's relationship with Beijing and Washington.

China presents New Zealand with a dilemma because core norms that resonate deeply with New Zealanders' sense of their identity as a liberal democratic nation are simply not shared with China. ${ }^{110}$ Moreover, a foreign policy of deep engagement with China pits many aspects of New Zealand's identity against its economic interests. Up to now, hard economic interests have won out. Moving forward, China has been our number one trading partner since 2017, and that aspect of our relationship can be expected to strengthen. As the vaccine for the coronavirus is disseminated, we can anticipate, among other things, a further consolidation of our trading relationship, with the free trade agreement updated in January 2021, increased numbers of Chinese students studying at our tertiary institutions once borders open, and increased two-way tourism and investment. ${ }^{111}$ On the broader foreign policy front, we can anticipate both sides to build on ties even as there is an implicit "agree to disagree" stance over specific issues, such as treatment of non-Han majority in Tibet and Xinjiang, political developments in Hong Kong, and the high-profile territorial disputes in the South China Sea and East China Sea.

Post-Cold War US-New Zealand relations have principally involved relationship repair. In this respect, the watershed event is clearly Wellington's prohibition of nuclear vessels in its waters in $1984 .{ }^{112} \mathrm{New}$ Zealand's non-nuclear posture prevented practical alliance 
cooperation under framework of ANZUS. Extensive efforts to resolve the issue proved unsuccessful. And in August 1986, the United States suspended its ANZUS security obligations to New Zealand, with Secretary of State George Shultz stating that "we remain friends, but we are no longer allies." ${ }^{113}$ Nevertheless, relations have improved with the passage of time.

On 4 November, 2010, the US (represented by Secretary of State Hillary Clinton) and New Zealand (represented by Prime Minister John Key and Foreign Minister Murray Stuart McCully) signed the Wellington Declaration, establishing a "New Strategic Partnership." ${ }^{114}$ This was followed up in June 2012 with the Washington Declaration. ${ }^{115}$ The Declaration calls for closer bilateral security cooperation, including increasing cooperation in the South Pacific, building New Zealand's capacity in peacekeeping, humanitarian assistance and disaster relief. By February 2013, comfort levels had risen enough that Prime Minister Key stated in an interview that "the relationship between New Zealand and the United States has never been better." 116 Indeed, notwithstanding Wellington's aversion to the nuclear dimension of great power politics, it is worth noting that there is a significant continuity in Wellington's foreign policy. New Zealand's participation in the 'Five Eyes' intelligence sharing network has been unaffected by the ANZUS termination. ${ }^{117}$ Here, New Zealand's geographical asset to the US lies in the area of signal intelligence, with facilities in Tangimoana, near Palmerston-North in the North Island, and in Waihopai Valley, near Blenheim in the South Island. ${ }^{118}$

Progress in bilateral relations is underlined in the 2017 NSS report, where New Zealand is identified as "a key US partner contributing to peace and security across the region." 119 Thus, President Biden inherits a relationship that in many respects is quite robust. And New Zealanders are positively disposed to reengage with a US that is more integrated in international institutions; focused on boosting regional economic interdependence; and less transactional in bilateral relations. Biden's statement that he wants to consult with allies and friends in developing his administration's China strategy will register well with the New Zealand government and electorate. ${ }^{120}$ That said, the double-edged sword nature of Biden's statement for New Zealand foreign policy has gone unnoticed and should be food for thought. ${ }^{121}$ In any case, at a symbolic level, it will certainly be noted in Wellington that Biden backed up his statement by including Prime Minister Jacinda Ardern in his round of personal telephone conversations with key US allies and partners in the Asia-Pacific region on 23 November 2020, well before he had a conversation with $\mathrm{Xi}$ on 10 February $2021 .{ }^{122}$ The challenge will be to build on the potential for bilateral relations that were unrealised during the Trump administration.

\section{Conclusion}

Sino-US relations were in deep trouble well before the Trump administration, which dealt the coup de grace to a US policy of near full-spectrum engagement with China. What has replaced that policy is best described as a competitive interest-based 
relationship, deeply rooted in great power politics. And given the structural origins of this rivalry, there is little reason to expect substantial improvements during President Biden's tenure. The central argument of this article-that power politics rather than state identities is the basic driver of the US-China relationship-illuminates a matter of the highest national interest for New Zealand. Moving forward, some of the more important questions facing New Zealand foreign policymakers are a corollary of the faltering Sino-US relationship. These include the following: How might New Zealand respond to a weakening and/or a strengthening of the cornerstone of the Asian security complex since 1945, namely, the US-alliance network? What is New Zealand's back up plan if, after the inevitable post-vaccine growth, regional growth stalls for whatever reason? How exactly should New Zealand diversify its sources of economic growth? How should we respond to the use of asymmetrical economic and/or military power by the major powers in the international system? What is our strategy for heightened great power politics in our immediate regions, the South Pacific and the Antarctic? Admittedly, these are challenging questions to grasp, and easier to pose than to answer. And, it may be that we have the good fortune to never have to put our answers to these questions into practice. But not to confront them is as ill-advised as indulging in nostalgia for a continuation for a liberal order that has already receded, as reflected in the unravelling of the post-1972 US China engagement policy. 
1 For an overview of the relationship from 1972-91, see Harry Harding, Fragile Relationship: The United States and China Since 1972 (Washington DC: Brookings Institution, 1992). For an overview from 1989 to 2020, see Nicholas Khoo, China's Foreign Policy Since 1978: Return to Power (Cheltenham, UK: Edward Elgar, 2020), pp.57-101.

2 Harry Harding, "Has U.S. China Policy Failed?" Washington Quarterly, 38 (3) (2015), p.118. DOI: 10.1080/0163660X.2015.1099027.

3 Harding, "Has U.S. China Policy Failed?," p.95.

4 Harding, "Has U.S. China Policy Failed?," p.119.

5 Office of the President of the United States [OPUS], National Security Strategy, 2017 (Washington

DC: 2017), p.45. Available at https://trumpwhitehouse.archives.gov/articles/new-national-security-strategy-new-era/.

OPUS, National Security Strategy, 2017, p.25.

6 Office of the President of the United States [OPUS], United States Strategic Approach to the People's Republic of China (Washington DC: 2020), p.7. Available at https://trumpwhitehouse.archives. gov/wp-content/uploads/2020/05/U.S.-Strategic-Approach-to-The-Peoples-Republic-of-China-Report5.24v1.pdf.

7 See Trump's reference to "cut[ing] off the whole relationship." "Trump Threat to Cut Off Trade Ties Over Covid-19 Branded 'Lunacy' by Chinese Media," Guardian, 14 May 2020. Available at https://www. theguardian.com/world/2020/may/15/global-report-trade-deal-fears-after-trump-threat-to-cut-china-tiesover-covid-19. See also Ali Wyne, "How to Think About Decoupling from China," Washington Quarterly, 43 (1) (2020), pp.41-64. DOI:10.1080/0163660X.2020.1735854.

8 Thus, the State Council advises the US to "treat our bilateral relations from a broad and rational perspective." State Council Information Office of the People's Republic of China [SCIO], China and the World in the New Era (Beijing: 2019), p.44. Available at http://english.www.gov.cn/archive/whitepaper/201909/27/content_WS5d8d80f9c6d0bcf8c4c142ef.html.

See also, "Trump administration's Specious China Policy Perfect Illustration of US' train-wreck diplomacy," Global Times, 22 November 2020. Available at https://www.globaltimes.cn/content/1207670. shtml; Ren Yi, a Harvard-trained writer and Chinese citizen based in Beijing noted that "mainstream Chinese have become disillusioned with America. The trade war was a catalyst. Then came [Trump's sanctions on] Huawei, TikTok, the use of American power against us, the dispute over the Hong Kong movement." "A U.S. China Détente Under Biden? Beijing Isn't Betting on it," Washington Post, 8 November 2020. Available at https://www.washingtonpost.com/world/asia_pacific/biden-election-chinatrump/2020/11/08/0932036a-1f5a-11eb-ad53-4c1fda49907d_story.html.

9 The concept of 'engagement' as used by successive US administrations to describe the US's China policy has been far from clear, being compatible with a variety of understandings including (but not limited to) the existence of basic diplomatic relations; a simple-minded engagement at all costs policy; or a quid-pro quo relationship. For an excellent discussion of the problems with the engagement concept, see Evan Resnick, "Defining Engagement," Journal of International Affairs, 54 (2) (2001), pp.551-566. http://www.jstor.org/stable/24357749.

10 For a clear statement of this point see: OPUS, United States Strategic Approach, p.16.

11 "Trump to Accuse China of Economic Aggression," Financial Times, 16 December 2017. Available at https://www.ft.com/content/1801d4f4-e201-11e7-8f9f-de1c2175f5ce.

12 OPUS, National Security Strategy, 2017, pp.2-3.

13 OPUS, National Security Strategy, 2017, p.25.

14 OPUS, National Security Strategy, 2017, p.46.

15 Office of the President of the United States [OPUS], National Security Strategy of the United States of America (Washington DC: 2015), p.24. Available at https://obamawhitehouse.archives.gov/sites/default/files/docs/2015_national_security_strategy_2.pdf.

16 Office of the President of the United States [OPUS], National Security Strategy of the United States of America (Washington DC: 2010), p.43. Available at https://obamawhitehouse.archives.gov/sites/default/files/rss_viewer/national_security_strategy.pdf.

17 Office of the President of the United States [OPUS], National Security Strategy of the United States of America (Washington DC: 2002), pp.27-28. Available at https://georgewbush-whitehouse.archives. gov/nsc/nss/2002/. 
18 Department of Defense, Summary of the National Defense Strategy of the United States (Washington DC: 2018), 2. Available at https://dod.defense.gov/Portals/1/Documents/pubs/2018-National-Defense-Strategy-Summary.pdf.

19 “Bush Makes Clinton's China Policy an Issue," Washington Post, 20 August 1999. Available at https://www.washingtonpost.com/wp-srv/politics/campaigns/wh2000/stories/chiwan082099.htm.

20 Department of Defense, [DOD] Summary of the National Defense Strategy of the United States (Washington DC: 2018), p.2. Available at https://dod.defense.gov/Portals/1/Documents/pubs/2018-National-Defense-Strategy-Summary.pdf.

21 Department of Defense [DOD], Indo-Pacific Strategy Report (Washington DC: 2019), pp.7-10. Available at https://media.defense.gov/2019/Jul/01/2002152311/-1/-1/1/DEPARTMENT-OF-DEFENSE-INDO-PACIFIC-STRATEGY-REPORT-2019.PDF.

22 DOD, Indo-Pacific Strategy Report, p.16.

23 OPUS, United States Strategic Approach, p.1.

24 This is reflected in the reality that the US has been China's top export trading partner on a country basis for much of the post-1978 reform era. See US Census Bureau foreign trade figures from 20042019 available at https:/www.census.gov/foreign-trade/statistics/highlights/top/index.html. See also entry for China at the World Bank's database. World Integrated Trade Solution (WITS), "China Trade Statistics," 18 February 2021. Available at https://wits.worldbank.org/CountryProfile/en/CHNhttps://wits. worldbank.org/CountryProfile/en/Country/CHN/Year/2018/TradeFlow/Export/Partner/USA/Product/AllGroups.

25 State Council of the People's Republic of China, China's National Defense (Beijing: July 1998). Available at http://china.org.cn/e-white/5/index.htm; See also Michael Pillsbury, China Debates the Future Security Environment (Washington DC: National Defense University Press, 2000), Chapter 2.

26 Quoted in "US Now a 'Threat' in China's Eyes," Washington Post, 15 November 2000. Available at https://www.washingtonpost.com/archive/politics/2000/11/15/us-now-a-threat-in-chinas-eyes/785813293277-4c6f-95a0-a7d98b380db8/.

27 Thus, the Taiwan and North Korean issues were finessed well by both the US and China. See Khoo, China's Foreign Policy Since 1978, pp.68-71.

28 Nina Silove, "The Pivot Before the Pivot: US Strategy to Preserve the Balance of Power in Asia," International Security, 40 (4) (Spring 2016), pp.45-88. DOI:10.1162/ISEC_a_00238.

29 Khoo, China's Foreign Policy Since 1978, pp.72-78.

30 See Ren Xiao, "US Rebalance to Asia and China's Responses," in No Author, America's Role in Asia (Seoul: Asia Foundation and Korean-American Association, 2015), pp.61-73. https://asiafoundation.org/resources/pdfs/ARAPublication082015.pdf.

31 Jiang Lingfei, "China's International Security Challenges and Response at Present and in the Coming Five Years," in China International Strategy Review 2012 [Zhongguo guoji zhanlue pinglun] (Beijing: Foreign Languages Press, 2013), p.159; See also, Chu Shulong and Tao Shasha, "Responding to our Peripheral Security Challenges," Contemporary International Relations [Xiandai guoji guanxi], 23 (6) (November/December 2013): p.10. Available at https://caod.oriprobe.com/issues/1472360/toc.htm.

32 See Khoo, China's Foreign Policy Since 1978, pp.82-85, pp.135-137.

33 United States Trade Representative Office, 2018 Report to Congress on China's WTO Compliance (Washington DC: 2019). Available at https://ustr.gov/sites/default/files/2018-USTR-Report-to-Congresson-China $\% 27$ s-WTO-Compliance.pdf.

34 “Trump Reaches 'Phase 1' Deal with China and Delays Planned Tariffs," New York Times, 11 October 2019. Available at https://www.nytimes.com/2019/10/11/business/economy/us-china-trade-deal. html; "What's In (and Not In) the US-China Trade Deal," New York Times, 15 January 2020. Available at https://www.nytimes.com/2020/01/15/business/economy/china-trade-deal-text.html

35 “On WHO Trip, China Refused to Hand Over Important Data,” New York Times, 12 February 2021. Available at https://www.nytimes.com/2021/02/12/world/asia/china-world-health-organization-coronavirus.html/.

36 "He Could Have Seen What Was Coming: Behind Trump's Failure on the Virus," New York Times, 11 April 2020. Available at https://www.nytimes.com/2020/04/11/us/politics/coronavirus-trump-response.html.

37 "The US was Beset by Denial and Dysfunction as the Coronavirus Raged," Washington Post, 4 April 2020. Available at https://www.washingtonpost.com/national-security/2020/04/04/coronavirus-govern- 
ment-dysfunction/?arc404=true. "Coronavirus in the US: Latest Map and Case Count," New York Times, 17 February 2021. https://www.nytimes.com/interactive/2020/us/coronavirus-us-cases.html.

38 "American and Chinese Officials Take Pulse on Trade Deal, Six Months In," New York Times, 14 September 2020. Available at https://www.nytimes.com/2020/08/24/business/economy/us-china-tradedeal.html; "2 Charts Show China's Shortfall in Buying US Goods Under the 'Phase One' Trade Deal," CNBC, 24 December 2020. https://www.cnbc.com/2020/12/24/chinas-progress-in-buying-us-goods-under-phase-one-trade-deal.html.

39 China's embassies and diplomats have encouraged countries and international organizations to make positive statements about China's response, and regardless of whether such a positive response has been received, portrayed the response as positive. "China is Using Coronavirus to Bully Europe," Daily Telegraph, 13 May 2020. Available at https:/www.telegraph.co.uk/politics/2020/05/13/china-using-covid-crisis-bully-europe/.

40 President Trump repeatedly focused on the World Health Organization's failure to more aggressively confront China over its handling of the outbreak in Wuhan. "Trump Announces Cut Off of New Funding for the World Health Organization Over Pandemic Response," Washington Post, 15 April 2020. Available at https://www.washingtonpost.com/politics/trump-announces-cutoff-of-new-funding-for-the-worldhealth-organization-over-pandemic-response/2020/04/14/f1df101e-7e9f-11 ea-a3ee-13e1ae0a3571_story. html.

41 Robert C. O'Brien, The Chinese Communist Party's Ideology and Global Ambitions, 26 June 2020. Available at https://www.whitehouse.gov/briefings-statements/chinese-communist-partys-ideology-global-ambitions/; Christopher Wray, The Threat Posed by the Chinese Government and the Chinese Communist Party to the Economy and National Security of the United States, 7 July 2020. Available at https://www.fbi.gov/news/speeches/the-threat-posed-by-the-chinese-government-and-the-chinese-communist-party-to-the-economic-and-national-security-of-the-united-states; William P. Barr, Remarks on China Policy at the Gerald R. Ford Presidential Museum, 16 July 2020. Available at

https://www.justice.gov/opa/speech/attorney-general-william-p-barr-delivers-remarks-china-policy-gerald-r-ford-presidential; Michael R. Pompeo, Communist China and the Free World's Future, 23 July 2020. Available at https://www.state.gov/communist-china-and-the-free-worlds-future/.

42 In addition to those cited in this paragraph, further examples can be found in the section: "An Openly Confrontational US-China Relationship," in US-China Economic and Security Review Commission, 2020 Report to Congress of the US-China Economic and Security Review Commission (Washington DC: December 2020), pp.364-367. Available at https://www.uscc.gov/annual-report/2020-annual-report-congress.

43 Defined as including businesses, companies, research institutes, individuals, government, private organizations, "and other types of legal persons." https://www.bloomberg.com/news/articles/2021-01-15/ what-do-the-two-u-s-blacklists-of-chinese-companies-do-q-a.

44 "What Do the Two US Blacklists of Chinese Companies Do?" Bloomberg, 16 January 2021. Available at https://www.bloomberg.com/news/articles/2021-01-15/what-do-the-two-u-s-blacklists-ofchinese-companies-do-q-a.

45 Khoo, China's Foreign Policy Since 1978, pp.84-85

46 "Latest US Sanctions Show that Trump Isn't Finished Hitting China," Bloomberg, 10 November 2020. Available at https://www.bloomberg.com/news/articles/2020-11-09/u-s-readies-more-sanctionsover-china-s-hong-kong-crackdown.

47 "Trump bans U.S. investments in companies linked to Chinese military," Reuters, 14 November 2020. Available at https://www.reuters.com/article/us-usa-china-securities-exclusive/trump-bans-u-s-investments-in-firms-linked-to-chinese-military-idUSKBN27S2X3.

48 "US Says China's Repression of Uighurs is Genocide," New York Times, 19 January 2021. Available at https://www.nytimes.com/2021/01/19/us/politics/trump-china-xinjiang.html.

49 "US Tightens Visa Rules for Communist Party Members," 3 December 2021. Available at https:// www.nytimes.com/2020/12/03/world/asia/us-visa-china-communist-party.html.

50 "Vast Dragnet Targets Theft of Biomedical Secrets for China," New York Times, 4 November 2019. Available at https://www.nytimes.com/2019/11/04/health/china-nih-scientists.html.

51 Mike Pompeo, The Chinese Communist Party on the American Campus, 9 December 2020. Available at https://www.state.gov/the-chinese-communist-party-on-the-american-campus/. 
52 “Trump Upsets Decades of US Policy on Taiwan, Leaving Thorny Questions for Biden,” Washington Post, 14 January 2021. Available at https://www.washingtonpost.com/world/asia_pacific/trumpbiden-taiwan-china/2021/01/13/1bbadee0-53c0-11eb-acc5-92d2819a1ccb_story.html.

53 "China Diplomat Warns U.S. Against Pushing to 'Brink of a New Cold War,'" Washington Post, 25 May 2020. Available at https://www.washingtonpost.com/world/asia_pacific/china-tells-us-to-stoptaking-them-to-the-brink-of-a-new-cold-war/2020/05/24/4eda6ffc-9da9-11ea-9d96-c3f7c755fd6e_story. html.

54 "China says ties with US at lowest point since 1979," Financial Times, 9 July 2020. Available at https://www.ft.com/content/cb2aab03-8a77-49fd-a928-b470948bebdf.

55 “'Caught in 'Ideological Spiral,' US and China Drift Toward Cold War," New York Times, 14 July 2020. Available at https://www.nytimes.com/2020/07/14/world/asia/cold-war-china-us.html.

56 "China Pledges to Retaliate after US Orders Closure of its Consulate in Houston," Washington Post, 23 July 2020. Available at https://www.washingtonpost.com/world/asia pacific/china-vowsto-retaliate-after-us-orders-closure-its-consulate-in-houston/2020/07/22/41e5c6ea-cbf1-11 ea-99b08426e26d203b_story.html.

57 "China Wasn't Wild about Mike Pompeo before the Virus. It's Really Gunning for Him Now." Washington Post, 1 May 2020. Available at https://www.washingtonpost.com/world/asia pacific/chinamike-pompeo-coronavirus-wuhan-lab/2020/04/30/1c9c8e8a-8acb-11ea-9759-6d20ba0f2c0e_story.html.

58 See the authoritative publication by the SCIO, China and the World, p.44.

59 SCIO, China and the World, p.45.

60 SCIO, China and the World, p.32.

61 "China urges U.S. to discard Cold-War mentality, zero-sum game mindset," Xinhua News Agency, 19 September, 2019. Available at http://www.xinhuanet.com/english/2019-09/16/c_138396255.htm.

62 Pompeo, Communist China and the Free World's Future.

63 Examples of analysts utilizing identity-based arguments to analyze contemporary world politics include: Robert Kagan, "The Strongmen Strike Back," Washington Post, 14 March 2019. Available at https://www.washingtonpost.com/news/opinions/wp/2019/03/14/feature/the-strongmen-strike-back/; Hal Brands, "Democracy vs Authoritarianism: How Ideology Shapes Great Power Conflict," Survival, 60 no. 5 (2018), pp. 61-114. DOI:10.1080/00396338.2018.1518371; Aaron Friedberg, "Competing with China," Survival, 60 no.3 (2018), pp.7-64. DOI:10.1080/00396338.2018.1470755; Bentley B. Allan, Srdjan Vucetic, and Ted Hopf, "The Distribution of Identity and the Future of the International Order: China's Hegemonic Prospects," International Organization, 72 (4) (Fall 2018), pp.839-869. DOI: $10.1017 / \mathrm{S} 00208183180002$.

64 For the US side, see Pompeo, Communist China and the Free World's Future. For the Chinese side, see the articulation of the Four Cardinal Principles by Xi in Xi Jinping, Secure a Decisive Victory in Building a Moderately Prosperous Society in All Respects and Strive for the Great Success of Socialism with Chinese Characteristics for a New Era. Speech delivered at the $19^{\text {th }}$ CCP Party Congress 18 October, p.10. Available at http://www.xinhuanet.com/english/download/Xi_Jinping\%27s_report_at_19th_ CPC_National_Congress.pdf.

65 In theoretical terms, such an explanation is consistent with either liberal democratic peace theory, or the identity strand of constructivist theory.

66 OPUS, National Security Strategy, 2017, p.25.

67 DOD, Indo-Pacific Strategy Report, 2019, Message from the Secretary of Defense.

68 OPUS, United States Strategic Approach, p.16.

69 OPUS, United States Strategic Approach, p.5.

70 OPUS, United States Strategic Approach, p.16.

71 Office of the Secretary of State [OSS], The Elements of the China Challenge (Washington DC: 2020), p.1. https://www.state.gov/wp-content/uploads/2020/11/20-02832-Elements-of-China-Challenge-508.pdf.

72 OSS, China Challenge, p.1.

73 Xi, "Secure a Decisive Victory," p.9.

74 The principles are: the Socialist Road; the Dictatorship of the Proletariat; the Leadership of the Communist Party; and adherence to Marxism-Leninism and Mao Zedong Thought. For further discus- 
sion see William A. Joseph, Politics in China: An Introduction $2^{\text {nd }}$ ed. (New York, Oxford University Press: 2010), p.156.

75 Page 4 of the 2017 PRC Constitution. Available at http://www.xinhuanet.com/english/special/2017-11/03/c 136725945.htm.

76 Xi Jinping, Uphold and Develop Socialism with Chinese Characteristics, Speech to the CCP Central Committee, 5 January 2013, in Tanner Greer, translation, "Xi Jinping in Translation: China's Guiding Ideology," Palladium, 31 May 2019. Available at https://palladiummag.com/2019/05/31/ xi-jinping-in-translation-chinas-guiding-ideology/.

$77 \mathrm{Xi}$, Secure a Decisive Victory, p.53.

$78 \mathrm{Xi}$, Secure a Decisive Victory, p.53.

79 “Pompeo Calls China's Ruling Party 'Central Threat of Our Times'," New York Times, 30 January 2020. Available at https://www.nytimes.com/2020/01/30/world/europe/pompeo-uk-china-huawei.html.

80 Pompeo, Communist China and the Free World's Future.

81 Pompeo, Communist China and the Free World's Future.

82 The 2020 President's Office report states that US China policy is "not premised on an attempt to change the PRC's domestic governance model." OPUS, United States Strategic Approach, 8. Interestingly, this argument can also be applied to China's US policy. The non-interference in the internal affairs of other states is one of China's Five Principles of Peaceful Coexistence. See Liselotte Odgaard, China and Coexistence: Beijing's National Security Strategy for the Twenty-First Century (Baltimore: Johns Hopkins University Press, 2012).

83 See US Census Bureau foreign trade figures from 2004-2019 available at https://www.census.gov/ foreign-trade/statistics/highlights/top/index.html.

84 Indeed, it is precisely the US's rejection of a preemptive containment policy in favour of a near full-spectrum post-Cold War era US engagement policy that is at the core of the offensive realist critique of US China engagement policy. John Mearsheimer, "The Future of the American Pacifier," Foreign Affairs, 80 (5) (September/October 2001), p.57. https://heinonline.org/HOL/P?h=hein.journals/ fora $80 \& \mathrm{i}=814$.

85 David Kang, China Rising: Power, Peace and Order in East Asia (New York: Columbia University Press, 2007), p.4, p.9, pp.20-21.

86 Kang, China Rising, p.10.

87 David Kang, "Why China's Rise Will Be Peaceful: Hierarchy and Stability in the East Asian Region," Perspectives on Politics 3 (3) (September 2005), p.552. https://www.jstor.org/stable/3689029.

88 Kang, China Rising, p. 4.

89 David Kang, "China's Rise: Intentions, Power and Evidence," in The Routledge Handbook of Security Studies. Myriam Dunn Cavelty and Victor Mauer eds. (New York: Routledge, 2010), pp.257-267.

90 David Shambaugh, "China Engages Asia: Reshaping the Regional Order," International Security, 29

(3) (2004/05), pp.64-99. https://www.jstor.org/stable/4137556.

91 David Shambaugh, "Coping with a Conflicted China," Washington Quarterly, 34 (1) (2011), pp. 7-27. DOI:10.1080/0163660X.2011.537974.

92 Note that I am using neorealist theory in its capacity as a theory of foreign policy. See Colin Elman, "Horses For Courses: Why Not Neorealist Theories of Foreign Policy?," Security Studies, 6 (1) (1996), pp.7-53. DOI:10.1080/09636419608429297. For an expanded version of this argument, see Khoo, China's Foreign Policy Since 1978, pp.57-101.

93 See Khoo, China's Foreign Policy Since 1978, pp.57-101.

94 Eric Heigenbotham, The US-China Military Scorecard: Forces, Geography, and the Evolving Balance of Power, 1996-2017 (Santa Monica: RAND, 2015).

95 Note the report's emphasis on China's "Marxist-Leninist beliefs," "authoritarian government," and "intellectual sources of China's conduct." OSS, China Challenge, p.1, p.8, p.27.

96 OSS, China Challenge, p.1, p.8.

97 John Lewis Gaddis, Strategies of Containment: A Critical Appraisal of American National Security Policy During the Cold War Rev. and Exp. Version (New York: Oxford University Press, 2005). 
98 Evan N. Resnick, "Strange Bedfellows: US Bargaining Behavior with Allies of Convenience," International Security, 35 (3) (Winter 2010/2011), pp.144-184. https://www.jstor.org/stable/40981255? seq=1.

99 Robert S. Ross, Negotiating Cooperation: The United States and China, 1969-1989 (Stanford: Stanford University Press, 1995).

100 OPUS, National Security Strategy, 2017, p.25.

101 OPUS, National Security Strategy, 2017, p.37.

102 OPUS, National Security Strategy, 2017, p.25.

103 Department of Defense, Indo-Pacific Strategy Report, p.10.

104 OPUS, United States Strategic Approach, p.2.

105 "Remarks by President Biden on America's Place in the World," US Department of State, 4

February 2021. Available at https://www.whitehouse.gov/briefing-room/speeches-remarks/2021/02/04/ remarks-by-president-biden-on-americas-place-in-the-world/.

106 "Remarks by President Biden."

107 Accordingly, Fudan University Professor Shen Dengli expects greater conflict under a Biden presidency. According to Shen, "Biden will try to do what Trump couldn’t - suppress China - because the distance between China and the U.S. is drawing closer every year, and no leader, Democratic or Republican, will ever accept China overtaking America. Pressure will be higher still come 2024." "A U.S. China Détente Under Biden? Beijing Isn't Betting on it," Washington Post, 8 November 2020. Available at https://www.washingtonpost.com/world/asia_pacific/biden-election-china-trump/2020/11/08/0932036a1f5a-11eb-ad53-4c1fda49907d_story.html.

108 “Trade Minister: NZ's economy needs to diversify and move away from China," Newstalk ZB, 30 April 2020. Available at

https://www.newstalkzb.co.nz/on-air/mike-hosking-breakfast/audio/david-parker-trade-minister-saysnzs-needs-to-diversify-and-and-move-away-from-china/.

109 Right Honorable Winston Peters' Speech to New Zealand US Council, 29 October 2019. Available at

https://www.amcham.co.nz/page-1334006/8081642; "NZ and China Upgrade Trade Agreement," Radio New Zealand, 26 January 2021. Available at https://www.rnz.co.nz/news/political/435211/new-zealandand-china-upgrade-free-trade-agreement.

110 This is highlighted most recently in the issue of international students from Hong Kong protesting PRC policy in their Special Administrative Region (SAR), with students from other parts of the PRC organizing counter protests, and the Consular General from the PRC consulate in Auckland supporting the latter group. "Hong Kong Protestors Gather at Auckland University," Stuff, 6 August 2019. Available at https://www.stuff.co.nz/auckland/114777487/hong-kong-protesters-gather-at-auckland-university.

111 "New Zealand-China Free Trade Agreement Text, 2008," New Zealand Foreign Affairs and Trade. https://www.mfat.govt.nz/en/trade/free-trade-agreements/free-trade-agreements-in-force/china-fta/ nz-china-fta-resources/.

112 Department of Defense, United States Security Strategy for the East Asia-Pacific Region (Washington DC: 1998), p.27. Available https://apps.dtic.mil/dtic/tr/fulltext/u2/a367522.pdf.

113 “Schultz Ends US Vow to Defend New Zealand," New York Times, 28 June 1986, p.5. Available at ttps://www.nytimes.com/1986/06/28/world/shultz-ends-us-vow-to-defend-new-zealand.html.

114 According to the US embassy in Wellington, there are two elements in this strategic partnership. To quote from the embassy website: "The United States-New Zealand strategic partnership is to have two fundamental elements: a new focus on practical cooperation in the Pacific region; and enhanced political and subject-matter expert dialogue - including regular Foreign Ministers' meetings and political-military discussions." Available at http://newzealand.usembassy.gov/wellington_declaration.html.

115 See New Zealand Foreign Affairs and Trade, "United States of America," Available at https://www. mfat.govt.nz/en/countries-and-regions/north-america/united-states-of-america.

116 “The Interview: New Zealand's Prime Minister John Key," The Diplomat, 8 February 2013. Available at http://thediplomat.com/2013/02/08/the-interview-new-zealands-prime-minister-john-key/2/.

117 On this point, see Paul G. Buchanan, "Lilliputian in Fluid Times: New Zealand Foreign Policy After the Cold War," Political Science Quarterly, 125 (2) (2010), pp.268-269. DOI: 10.1002/j.1538165X.2010.tb00675.x. 
118 David Brown, “The Biggest Little Diplomatic Crisis You've Never Heard of,” Atlantic Monthly, 11 November 2011. Available at https://www.theatlantic.com/international/archive/2011/11/the-biggest-little-diplomatic-crisis-youve-never-heard-of/248302/.

119 OPUS, National Security Strategy, 2017, p.47.

120 "According to Biden, "The best China strategy, I think, is one which gets every one of our - or at least what used to be our - allies on the same page. It's going to be a major priority for me in the opening weeks of my presidency to try to get us back on the same page with our allies." "Biden Made Sure 'Trump Is Not Going to Be President for Four More Years,"” New York Times, 2 December 2020. Available at https://www.nytimes.com/2020/12/02/opinion/biden-interview-mcconnell-china-iran.html. 121 As my colleague Reuben Steff has commented: "New Zealand should be careful what it wishes for the US will want more out of its allies to challenge China. Even if this is generally a rhetorical statement of diplomatic negotiating positions, China could interpret this as US allies and partners 'siding' with the US against Chinese interests.” Author's email exchange with Reuben Steff, 15 February 2021.

122 “Ardern Speaks with US President-elect Joe Biden," Radio New Zealand, 23 November 2020. Available at https://www.rnz.co.nz/news/political/431262/ardern-speaks-with-us-president-elect-joebiden; "Readout of President Joseph R. Biden Jr. Call With President Xi Jinping of China," US Department of State, 4 February 2021. Available at https://www.whitehouse.gov/briefing-room/statements-releases/2021/02/10/readout-of-president-joseph-r-biden-jr-call-with-president-xi-jinping-of-china/. 